\title{
Invasive Indo-Pacific lionfish Pterois volitans reduce recruitment of Atlantic coral-reef fishes
}

\author{
Mark A. Albins*, Mark A. Hixon \\ Department of Zoology, Oregon State University, 3029 Cordley Hall, Corvallis, Oregon 97331, USA
}

\begin{abstract}
The Indo-Pacific lionfish Pterois volitans, introduced to Florida waters in the early 1990s, is currently spreading rapidly throughout the Caribbean region. This invasive carnivore may cause deleterious changes in coral-reef ecosystems via predation on native fishes and invertebrates as well as competition with native predators. We conducted a controlled field experiment using a matrix of translocated coral and artificial patch reefs to examine the short-term effects of lionfish on the recruitment of native reef fishes in the Bahamas. Lionfish caused significant reductions in the recruitment of native fishes by an average of $79 \%$ over the $5 \mathrm{wk}$ duration of the experiment. This strong effect on a key life stage of coral-reef fishes suggests that invasive lionfish are already having substantial negative impacts on Atlantic coral reefs. While complete eradication of lionfish in the Atlantic is likely impossible, it would be prudent to initiate focused lionfish control efforts in strategic locations.
\end{abstract}

KEY WORDS: Invasive species $\cdot$ Predation $\cdot$ Community interactions $\cdot$ Piscivory $\cdot$ Marine fishes

\section{INTRODUCTION}

Biological invasions are a leading cause of biodiversity loss and represent a substantial contribution to human-caused global change (Carlton \& Geller 1993, Wilcove et al. 1998). While invasions by marine fishes are relatively uncommon and their ecological effects are largely unknown, introductions of predatory freshwater fishes have often proven to be devastating to native communities (Helfman 2007).

Two closely related species of predatory lionfish (Pterois volitans and $P$. miles) were recently introduced from their native range in the Indo-Pacific to the Western Atlantic (Hamner et al. 2007). Genetic evidence of a strong founder effect suggests either a single introduction of a small founding population or multiple introductions of individuals with the same haplotype (Hamner et al. 2007). Lionfish may have been introduced into the Atlantic at Biscayne Bay, Florida, when several individuals were released from an aquarium during Hurricane Andrew in 1992 (Courtenay 1995, Hamner et al. 2007). Whether the introduction of lionfish to the Atlantic occurred as a single event or multi- ple events, it is likely that the source of the introduction was intentional or unintentional release from aquaria off the coast of Florida (Whitfield et al. 2002, Hare \& Whitfield 2003, Semmens et al. 2004, RuizCarus et al. 2006).

Between 1992 and 2006, lionfish spread rapidly northward along the eastern seaboard of the USA and southward into the Caribbean. They have now been sighted as far east as Bermuda, as far north as Rhode Island, and as far south as Jamaica (Whitfield et al. 2002, Hare \& Whitfield 2003, Whitfield et al. 2007), with unconfirmed reports from the Yucatan Peninsula, Puerto Rico, and the Lesser Antilles (L. Akins, REEF, pers. comm.), and they are now fairly common in the Bahamian archipelago off Florida. While Pterois volitans and $P$. miles are difficult to distinguish morphologically due to some overlap in meristic values, genetic evidence indicates that $P$. volitans is the only introduced lionfish currently found in the Bahamas (D.W. Freshwater et al., UNCW, pers. comm.).

We have studied coral reefs in the $200 \times 70 \mathrm{~km}$ Exuma Sound of the Bahamas since the early 1990s. In the summer of 2005, we found our first lionfish near 
Lee Stocking Island (LSI), one of our primary study sites. In 2006, we collected another lionfish at LSI and one near Eleuthera. During this same year, other researchers documented sightings of several individuals in the Abacos on Little Bahama Bank (Snyder \& Burgess 2007).

Between the fall of 2006 and the summer of 2007, the lionfish population in the Bahamas increased substantially. During the summer of 2007, we sighted over 100 individual lionfish in the vicinity of LSI, 3 in the Exuma Cays Land and Sea Park, and 2 at Cat Island. The clear increase in lionfish numbers at these regularly visited study sites indicated an extremely rapid expansion within the Bahamas.

Between June and September of 2007, we documented recruitment of newly settled lionfish to a matrix of 48 experimental patch reefs near LSI. We observed recruitment of 24 lionfish to these ca. $3 \mathrm{~m}^{2}$ experimental reefs over a $70 \mathrm{~d}$ period. Extrapolated, this pattern would be equivalent to a recruitment rate of ca. 24 fish ha ${ }^{-1}$ of hard substrate per day, although settlement may be greater, per unit area, to patch reefs than to continuous reefs.

The lionfish represents a potential major threat to coral-reef ecosystems in the Caribbean region by decreasing survival of a wide range of native reef animals via both predation and competition. Adults (300 to $400 \mathrm{~g}$ ) in the Indo-Pacific are reported to consume ca. $8.5 \mathrm{~g}$ of prey $\mathrm{d}^{-1}$, which translates to ca. $230 \mathrm{~kg} \mathrm{yr}^{-1}$ for 80 adult fish on a $1 \mathrm{~km}$ reef (Fishelson 1997). Lionfish herd and corner prey using ornate oversized pectoral fins and attack with a rapid strike (Allen \& Eschmeyer 1973, Fishelson 1997). Naivety of Atlantic prey to this novel predation strategy may result in high predation efficiency of lionfish relative to its native range, as well as compared to similarly-sized native predators in the invaded system. High predation efficiency may translate into a large ecological effect of lionfish, both on native prey species and on potential competitors.

Lionfish may be cannibalistic, but otherwise have few documented natural predators in their native range (Bernadsky \& Goulet 1991). While it is important to mention that extensive studies of predation on lionfish have not been reported, the apparent paucity of natural predators may be due, in part, to the defensive dorsal, anal, and pelvic spines of lionfish, which deliver a potent venom that may be fatal to fishes (Allen \& Eschmeyer 1973). It is likely that few native Atlantic (including Caribbean) species represent significant potential predators of lionfish. Despite recent evidence that native groupers may prey on lionfish (Maljković et al. 2008), such largebodied predators have been systematically overfished throughout the region (Sadovy \& Eklund 1999) and thus are not likely to substantially reduce the effects of invasive lionfish on Atlantic coral-reef communities.

Predation on post-settlement reef fishes represents an important and disproportionately large component of overall mortality and may have a strong effect on population densities as well as the structure of reef-fish communities (Carr \& Hixon 1995, Almany \& Webster 2006). Because lionfish may be particularly effective predators on small post-settlement reef fishes, they may potentially have large effects on native coral-reef fish populations and communities. Here we report the results of a field experiment designed to determine whether, and to what extent, lionfish affect recruitment of native coral-reef fishes.

\section{MATERIALS AND METHODS}

We conducted a controlled field experiment to examine the effects of lionfish on coral-reef fish recruitment at LSI in the Bahamas. We used an existing matrix of $3 \mathrm{~m}^{2}$ translocated live-coral patch reefs and $1 \mathrm{~m}^{2}$ artificial concrete-block reefs, all of which were constructed and deployed in the early 1990s and are now essentially natural features (Carr \& Hixon 1995, 1997, Hixon \& Carr 1997). These experimental reefs are separated from the nearest natural reefs by at least $1 \mathrm{~km}$ and from each other by $200 \mathrm{~m}$ (Fig. 1a). An initial survey of all experimental reefs confirmed that no lionfish were present at the outset of the experiment. During this initial survey we also counted all strongly interacting fish species, including territorial damselfishes and resident piscivores, which are known to have negative effects on the recruitment of reef fishes in the Bahamas (Carr et al. 2002). Twenty reefs (10 translocated and 10 artificial) were paired based on spatial proximity (Fig. 1b) and similarity of the pre-existing communities, as determined by the number of fish in major groups of known strong interactors (Table 1). Reef pairings were used to account for potential spatial variability in recruitment and the potential effects of members of the pre-existing community on post-settlement survival of reef fishes. One reef in each pair was designated as a control reef (lionfish absent) and the other as a treatment reef (lionfish present). Single lionfish were then transplanted from nearby reefs to each of the lionfishpresent reefs. Transplanted lionfish ranged in size from 11.8 to $28.5 \mathrm{~cm}$ total length $(\mathrm{TL})$ (mean $=16.5 \mathrm{~cm}$ TL). Following lionfish transplants, fish recruitment censuses were conducted at ca. $1 \mathrm{wk}$ intervals for $5 \mathrm{wk}$ during the summer 2007 recruitment period (July to August). Recruitment censuses were conducted by 2 divers using SCUBA, who counted all recruits $<5 \mathrm{~cm}$ TL on each reef. 

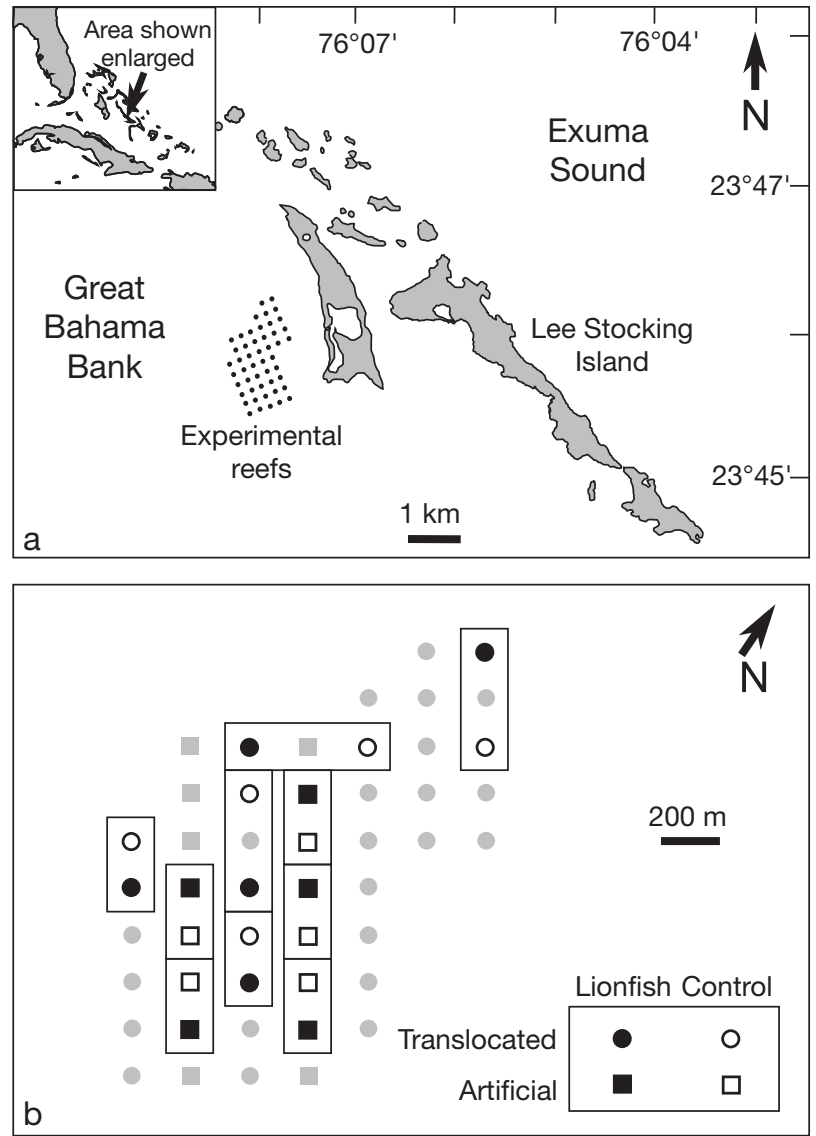

Fig. 1. (a) Matrix of experimental patch reefs near Lee Stocking Island, Bahamas. (b) Experimental design, showing treatment assignments, reef types, and reef pairs (boxes). Grey symbols represent unused reefs. Map redrawn from Almany (2003)

Because this experiment ran during the larval recruitment season, we expected to see overall increases in the number of small reef fish on all reefs over the course of the study period (i.e. positive net recruitment). However, we also predicted that net recruitment would be lower on lionfish treatment reefs than on control reefs.

We used a multi-way analysis of variance model, with treatment and reef type as explanatory factors and reef pair as an error term, to draw inferences regarding the effect of lionfish on net recruitment. Visual examination of standardized residuals vs. fitted values, as well as stratum-three residuals vs. normal quantiles, indicated that the data conformed to the assumptions of homogeneity of variances and normality.

\section{RESULTS}

Net recruitment was significantly lower on lionfish reefs than on control reefs at the end of the $5 \mathrm{wk}$ exper-
Table 1. Numbers of native strong-interactor fishes on experimental reefs. Treatments - L: lionfish present; C: lionfish absent (control). Large piscivores include $>30 \mathrm{~cm}$ total length (TL) Nassau grouper Epinephelus striatus and moray eels Gymnothorax spp. Small piscivores include coney grouper Cephalopholis fulva and graysby grouper C. cruentata. Aggressive damselfish include $>3 \mathrm{~cm}$ TL beaugregory, cocoa, and dusky damselfishes (Stegastes leucostictus, S. variabilis, and $S$. adustus, respectively)

\begin{tabular}{|c|c|c|c|c|c|}
\hline $\begin{array}{l}\text { Reef } \\
\text { pair }\end{array}$ & $\begin{array}{l}\text { Treat- } \\
\text { ment }\end{array}$ & $\begin{array}{c}\text { Large } \\
\text { piscivores }\end{array}$ & $\begin{array}{c}\text { Small } \\
\text { piscivores }\end{array}$ & $\begin{array}{l}\text { Aggressive } \\
\text { damselfish }\end{array}$ & Total \\
\hline \multicolumn{6}{|c|}{ Translocated reefs } \\
\hline \multirow[t]{2}{*}{1} & $\mathrm{~L}$ & 0 & 0 & 0 & 0 \\
\hline & $\mathrm{C}$ & 0 & 0 & 5 & 5 \\
\hline \multirow[t]{2}{*}{2} & $\mathrm{~L}$ & 0 & 0 & 5 & 5 \\
\hline & $\mathrm{C}$ & 0 & 0 & 5 & 5 \\
\hline \multirow[t]{2}{*}{3} & $\mathrm{~L}$ & 0 & 0 & 5 & 5 \\
\hline & $\mathrm{C}$ & 0 & 1 & 7 & 8 \\
\hline \multirow[t]{2}{*}{4} & $\mathrm{~L}$ & 2 & 0 & 1 & 3 \\
\hline & $\mathrm{C}$ & 0 & 1 & 6 & 7 \\
\hline \multirow[t]{2}{*}{5} & $\mathrm{~L}$ & 1 & 1 & 2 & 4 \\
\hline & $\mathrm{C}$ & 1 & 1 & 7 & 9 \\
\hline \multirow[t]{2}{*}{ Total } & $\mathbf{L}$ & 3 & 1 & 13 & 17 \\
\hline & C & 1 & 3 & 30 & 34 \\
\hline \multicolumn{6}{|c|}{ Artificial reefs } \\
\hline \multirow[t]{2}{*}{6} & $\mathrm{~L}$ & 2 & 1 & 0 & 3 \\
\hline & $\mathrm{C}$ & 3 & 0 & 3 & 6 \\
\hline \multirow[t]{2}{*}{7} & L & 1 & 0 & 1 & 2 \\
\hline & $\mathrm{C}$ & 2 & 0 & 1 & 3 \\
\hline \multirow[t]{2}{*}{8} & $\mathrm{~L}$ & 2 & 0 & 3 & 5 \\
\hline & $\mathrm{C}$ & 2 & 1 & 3 & 6 \\
\hline \multirow[t]{2}{*}{9} & $\mathrm{~L}$ & 0 & 0 & 0 & 0 \\
\hline & $\mathrm{C}$ & 1 & 0 & 0 & 1 \\
\hline \multirow[t]{2}{*}{10} & $\mathrm{~L}$ & 0 & 1 & 0 & 1 \\
\hline & $\mathrm{C}$ & 2 & 0 & 0 & 2 \\
\hline \multirow[t]{2}{*}{ Total } & $\mathbf{L}$ & 5 & 2 & 4 & 11 \\
\hline & C & 10 & 1 & 7 & 18 \\
\hline \multicolumn{6}{|c|}{ Totals for all reefs combined } \\
\hline & $\mathbf{L}$ & 8 & 3 & 17 & 28 \\
\hline & $\mathbf{C}$ & 11 & 4 & 37 & 52 \\
\hline
\end{tabular}

iment $(F=6.182, \mathrm{p}=0.038$, Fig. 2). Lionfish reduced net recruitment by a mean of 28.1 fish reef $^{-1}(95 \%$ CI of 2.2 to 54.0 fish reef $^{-1}$ ), representing an average reduction in net recruitment of $79 \%$. There was no evidence of a difference in net recruitment between translocated and artificial reefs, although the power of the test was low $(F=0.084, \mathrm{p}=0.779$, power $=0.364)$, and there was no evidence of an interaction between reef type and treatment $(F=1.263, \mathrm{p}=0.294$, power $=0.887)$. There was also no evidence of a difference between control and lionfish reefs in the number of small fishes present at the beginning of the experiment $(F=1.77, \mathrm{p}=0.221$, power $=0.931$ ).

During the experiment, 49 species of reef fish from 16 families recruited to the study reefs, with 38 species from 14 families recruiting to both lionfish and control reefs. Of these 38 species, 23 suffered reduced recruit- 


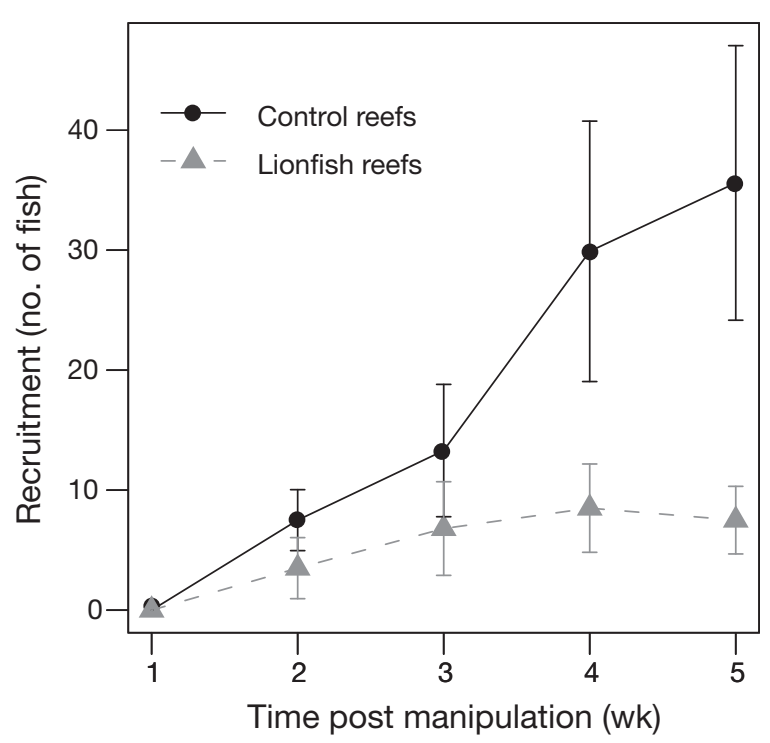

Fig. 2. Recruitment (mean \pm SE) of juvenile fish to experimental patch reefs after lionfish were transplanted onto 10 reefs, with 10 other reefs serving as lionfish-free controls. Recruitment was measured as the number of small fish present on each reef at the beginning of the experimental period subtracted from the number of small fish present on each reef during subsequent censuses (i.e. net accumulation of new recruits). Recruitment at Week 5 represents net recruitment over the experimental period because daily settlement and mortality were not monitored

ment in the presence of lionfish. Four of the 5 species of parrotfish (Family Scaridae) recruiting to both lionfish and control reefs suffered reduced recruitment in the presence of lionfish (Table 2).

Stomach content analyses and observations of feeding behavior showed that reductions in recruitment were almost certainly due to predation. Stomach contents were examined from all 10 fish used in the field experiment ( 9 of which had consumed fish) as well as from 42 additional lionfish collected from various sites around Exuma Sound. Of the 52 stomachs examined, 48 contained identifiable food items, including whole fish, fish parts, and small crustacean parts. In 14 cases, prey items were identifiable to the species level, including the fairy basslet Gramma loreto, bridled cardinalfish Apogon aurolineatus, white grunt Haemulon plumierii, bicolor damselfish Stegastes partitus, several wrasses Halichoeres bivittatus, H. garnoti, and Thalassoma bifasciatum, striped parrotfish Scarus iserti, and dusky blenny Malacoctenus gilli. Stomach content examination also confirmed that individual lionfish ate both large quantities of prey $(\max .=53$, mean $=5.7)$ and large prey relative to their body size. Fish prey ranged in size from 1 to $12 \mathrm{~cm}$ TL. One $11.9 \mathrm{~cm}$ TL lionfish contained a
Table 2. Mean net recruitment of fishes on experimental reefs. Mean net recruitment is the mean difference between the number of fish $<5 \mathrm{~cm}$ total length (TL) present on experimental reefs at the final (Week 5) census and the number present at the initial (Week 1) census (dnr indicates that the species did not recruit to any of the reefs of that type). The lionfish effect was calculated as the mean net recruitment to lionfish reefs minus mean net recruitment to control reefs for each species (a negative effect indicates that lionfish reduced recruitment). The lionfish effect was only calculated for species that recruited to both lionfish and control reefs

\begin{tabular}{|c|c|c|c|c|}
\hline Family & Species & $\begin{array}{r}\text { Mea } \\
\text { recru } \\
\text { Control } \\
\mathrm{n}=10\end{array}$ & $\begin{array}{l}\text { net } \\
\text { Lionfish } \\
n=10\end{array}$ & $\begin{array}{l}\text { Lion- } \\
\text { fish } \\
\text { effect }\end{array}$ \\
\hline Holocentridae & $\begin{array}{l}\text { Myripristis jacobus } \\
\text { Sargocentron coruscum }\end{array}$ & $\begin{array}{l}0 \\
0\end{array}$ & $\begin{array}{c}0 \\
-0.6\end{array}$ & $\begin{array}{c}0 \\
-0.6\end{array}$ \\
\hline Serranidae & $\begin{array}{l}\text { Cephalopholis fulva } \\
\text { Serranus tigrinus }\end{array}$ & $\begin{array}{l}0 \\
0.2\end{array}$ & $\begin{array}{l}0 \\
0.1\end{array}$ & $\begin{array}{c}0 \\
-0.1\end{array}$ \\
\hline Apogonidae & $\begin{array}{l}\text { Apogon aurolineatus } \\
\text { A. binotatus } \\
\text { A. maculatus } \\
\text { A. townsendi }\end{array}$ & $\begin{array}{l}0 \\
0.1 \\
0.6 \\
\text { dnr }\end{array}$ & $\begin{array}{c}\text { dnr } \\
\text { dnr } \\
-0.1 \\
0\end{array}$ & -0.7 \\
\hline Lutjanidae & Ocyurus chrysurus & 0 & -0.1 & -0.1 \\
\hline Haemulidae & $\begin{array}{l}\text { Haemulon melanurum } \\
\text { H. plumierii } \\
\text { Haemulon sp. (juvenile) }\end{array}$ & $\begin{array}{r}4.3 \\
-0.7 \\
-0.8\end{array}$ & $\begin{array}{c}0.3 \\
-0.7 \\
0\end{array}$ & $\begin{array}{l}-4 \\
0 \\
0.8\end{array}$ \\
\hline Mullidae & Pseudupeneus maculatus & IS 0 & 0 & 0 \\
\hline Chaetodontidae & $\begin{array}{l}\text { Chaetodon capistratus } \\
\text { C. ocellatus } \\
\text { C. sedentarius } \\
\text { C. striatus }\end{array}$ & $\begin{array}{c}-0.1 \\
0 \\
-0.1 \\
0\end{array}$ & $\begin{array}{l}\text { dnr } \\
0 \\
-0.1 \\
\text { dnr }\end{array}$ & $\begin{array}{l}0 \\
0\end{array}$ \\
\hline Pomacanthidae & Holacanthus ciliaris & 0.2 & dnr & \\
\hline Pomacentridae & $\begin{array}{l}\text { Stegastes diencaeus } \\
\text { S. leucostictus } \\
\text { S. partitus } \\
\text { S. variabilis }\end{array}$ & $\begin{array}{r}0.1 \\
0.5 \\
-0.4 \\
0.2\end{array}$ & $\begin{array}{r}\text { dnr } \\
1.2 \\
-0.6 \\
0.1\end{array}$ & $\begin{array}{r}0.7 \\
-0.2 \\
-0.1\end{array}$ \\
\hline Labridae & $\begin{array}{l}\text { Bodianus rufus } \\
\text { Halichoeres garnoti } \\
\text { H. maculipinna } \\
\text { H. pictus } \\
\text { H. poeyi } \\
\text { H. radiatus } \\
\text { Thalassoma bifasciatum }\end{array}$ & $\begin{array}{r}-0.3 \\
0.1 \\
-0.3 \\
2.5 \\
0.7 \\
-0.2 \\
-0.9\end{array}$ & $\begin{array}{l}-0.2 \\
-0.3 \\
-0.7 \\
-0.4 \\
0 \\
0 \\
-0.5\end{array}$ & $\begin{array}{r}0.1 \\
-0.4 \\
-0.4 \\
-2.9 \\
-0.7 \\
0.2 \\
0.4\end{array}$ \\
\hline Scaridae & $\begin{array}{l}\text { Cryptotomus roseus } \\
\text { Scarus taeniopterus } \\
\text { Sparisoma atomarium } \\
\text { Sparisoma aurofrenatum } \\
\text { Sparisoma viride } \\
\text { Unknown parrotfish }\end{array}$ & $\begin{array}{c}0.3 \\
-0.1 \\
0.3 \\
2.4 \\
2 \\
\text { dnr }\end{array}$ & $\begin{array}{r}0.1 \\
0 \\
0.2 \\
-0.2 \\
1.5 \\
0\end{array}$ & $\begin{array}{r}-0.2 \\
0.1 \\
-0.1 \\
-2.6 \\
-0.5\end{array}$ \\
\hline Labrisomidae & $\begin{array}{l}\text { Malacoctenus gilli } \\
\text { M. macropus } \\
\text { M. triangulatus }\end{array}$ & $\begin{array}{r}1.9 \\
0.3 \\
-0.2\end{array}$ & $\begin{array}{r}-0.6 \\
0.1 \\
-0.1\end{array}$ & $\begin{array}{r}-2.5 \\
-0.2 \\
0.1\end{array}$ \\
\hline Callionymidae & Callionymus bairdi & 0.1 & dnr & \\
\hline Gobiidae & $\begin{array}{l}\text { Coryphopterus dicrus } \\
\text { C. glaucofraenum } \\
\text { Gnatholepis thompsoni } \\
\text { Gobiosoma genie } \\
\text { Unknown goby } \\
\text { Unknown sponge goby } \\
\text { Priolepis hipoliti }\end{array}$ & $\begin{array}{r}0.2 \\
11.9 \\
10.4 \\
-0.1 \\
\text { dnr } \\
0.1 \\
0.5\end{array}$ & $\begin{array}{l}0 \\
4.4 \\
3.4 \\
0 \\
0 \\
\text { dnr } \\
0.4\end{array}$ & $\begin{array}{l}-0.2 \\
-7.5 \\
-7 \\
0.1\end{array}$ \\
\hline Acanthuridae & $\begin{array}{l}\text { Acanthurus chirurgus } \\
\text { A. coeruleus }\end{array}$ & $\begin{array}{r}-0.2 \\
0.2\end{array}$ & $\begin{array}{c}0 \\
-0.1\end{array}$ & $\begin{array}{r}0.2 \\
-0.3\end{array}$ \\
\hline Tetraodontidae & $\begin{array}{l}\text { Canthigaster rostrata } \\
\text { TOTAL }\end{array}$ & $\begin{array}{c}0 \\
35.5\end{array}$ & $\begin{array}{r}-0.1 \\
6.9\end{array}$ & $\begin{array}{r}-0.1 \\
-28.1\end{array}$ \\
\hline
\end{tabular}


Table 3. List of species eaten by lionfish in aquaria

\begin{tabular}{|ll|}
\hline Family & Species \\
\hline Haemulidae & Haemulon melanurum \\
Pomacentridae & Stegastes leucostictus \\
Labridae & Halichoeres pictus \\
Opistognathidae & Opistognathus aurifrons \\
Gobiidae & Gnatholepis thompsoni \\
& Coryphopterus glaucofraenum \\
\hline
\end{tabular}

$5.4 \mathrm{~cm}$ TL white grunt for a maximum observed prey: predator size ratio of 0.44 . Initial examination of crustacean prey suggested that lionfish may also eat the juvenile spiny lobster Panulirus argus, an important subsistence and commercial fishery species.

In the field, we observed lionfish stalking and feeding on several different reef-fish species throughout the daylight hours, with no indication that lionfish behaved in a way consistent with interference competition (e.g. aggression). On one occasion, we observed a large adult lionfish consume over 20 small wrasses Halichoeres bivittatus (1 to $3 \mathrm{~cm}$ TL) during a $30 \mathrm{~min}$ period.

Lionfish removed from nearby reefs and held in aquaria ate a wide variety of native reef fishes, including 6 different species from 5 families (Table 3). Consistent with our field observations, captive lionfish ate both large volumes of small fish as well as large fish in relation to their body size. It was not unusual to observe lionfish consuming prey up to $2 / 3$ of their own length. This pattern was especially apparent in smaller lionfish, including newly settled individuals. For example, one $3.1 \mathrm{~cm}$ TL lionfish recruit cornered and consumed a $2.0 \mathrm{~cm}$ TL cottonwick grunt Haemulon melanurum.

\section{DISCUSSION}

The present study represents the first experimental evidence that the invasive Indo-Pacific lionfish has a direct negative effect on Atlantic coral-reef fish populations.

The documented reduction in net recruitment due to lionfish predation is an important component, but likely represents an underestimation of the overall effects of lionfish on native reef-fish communities. The large reduction in recruitment suggests the possibility that lionfish may compete with native piscivores by monopolizing this important food resource. Also, by decreasing recruitment of fishes, lionfish have the potential to decrease the abundance of ecologically important species, such as parrotfishes and other herbivorous reef fishes, which are crucial for preventing seaweeds from overgrowing corals (Williams \& Polunin 2001, Mumby et al. 2006). Considering the sizes of lionfish currently found in the Atlantic (up to $45 \mathrm{~cm}$ TL, Whitfield et al. 2007), and the size of prey fish found in stomach contents, the effects of lionfish predation on adult fish is also likely to represent a significant impact of this invasive species on native communities. It is also important to note that lionfish have the potential to act synergistically with other existing stressors, such as climate change, overfishing, and pollution, making this invasion of particular concern for the future of Atlantic coral reefs.

The current geographic extent and rapid population growth of lionfish in the Atlantic makes complete eradication of this invasive species untenable. Nonetheless, it would be prudent for affected nations to initiate targeted lionfish control efforts as soon as possible. Concerted and sustained efforts to reduce densities of lionfish at key locations, including potential 'choke' or dispersal points (Hare \& Whitfield 2003), as well as particularly vulnerable or valuable reef areas, may help to mitigate their ecological impacts. Recovering and maintaining healthy populations of potential native predators of lionfish, such as large grouper and sharks, may also help reduce the deleterious effects of these voracious invasive predators.

Acknowledgements. We thank D. W. Johnson, R. W. Lamb, T. J. Pusack, and C. D. Stallings for assistance in the field, and B. Gadd of the Perry Institute for Marine Science for logistical support. M. R. Christie, K. N. Page-Albins, C. D. Stallings, P. E. Whitfield, and an anonymous referee provided reviews, and D. W. Johnson and L. Madsen reviewed the statistical analyses. This research was supported by a National Science Foundation Graduate Research Fellowship (to M.A.A.) and National Science Foundation research grant 05-50709 (to M.A.H.).

\section{LITERATURE CITED}

Allen GR, Eschmeyer WN (1973) Turkeyfishes at Eniwetok. Pac Discovery 26:3-11

Almany GR (2003) Priority effects in coral reef fish communities. Ecology 84(7):1920-1935

Almany GR, Webster MS (2006) The predation gauntlet: early post-settlement mortality in reef fishes. Coral Reefs 25: $19-22$

Bernadsky G, Goulet D (1991) A natural predator of the lionfish, Pterois miles. Copeia 1991:230-231

Carlton JT, Geller JB (1993) Ecological roulette: the global transport of nonindigenous marine organisms. Science 261:78-82

Carr MH, Hixon MA (1995) Predation effects on early postsettlement survivorship of coral-reef fishes. Mar Ecol Prog Ser 124:31-42

Carr MH, Hixon MA (1997) Artificial reefs: the importance of comparisons with natural reefs. Fisheries 22:28-33

Carr MH, Anderson TW, Hixon MA (2002) Biodiversity, population regulation, and the stability of coral-reef fish communities. Proc Natl Acad Sci USA 99:11241-11245 
Courtenay WR (1995) Marine fish introductions in southeastern Florida. Am Fish Soc Introduced Fish Newsl $14: 2-3$

Fishelson L (1997) Experiments and observations on food consumption, growth and starvation in Dendrochirus brachypterus and Pterois volitans (Pteroinae, Scorpaenidae). Environ Biol Fishes 50:391-403

Hamner RM, Freshwater DW, Whitfield PE (2007) Mitochondrial cytochrome $\mathrm{b}$ analysis reveals two invasive lionfish species with strong founder effects in the western Atlantic. J Fish Biol 71:214-222

Hare JA, Whitfield PE (2003) An integrated assessment of the introduction of lionfish (Pterois volitans/miles complex) to the western Atlantic Ocean. NOAA Tech Memo NOS NCCOS 2:1-21

Helfman GS (2007) Fish conservation: a guide to understanding and restoring global aquatic biodiversity and fishery resources. Island Press, Washington, DC

Hixon MA, Carr MH (1997) Synergistic predation, density dependence, and population regulation in marine fish. Science 277:946-949

Maljković A, Van Leeuwen TE, Cove SN (2008) Predation on the invasive red lionfish, Pterois volitans (Pisces: Scorpaenidae), by native groupers in the Bahamas. Coral Reefs. doi:10.1007/s00338-008-0372-9

Mumby PJ, Dahlgren CP, Harborne AR, Kappel CV and others (2006) Fishing, trophic cascades, and the process of grazing on coral reefs. Science 311:98-101

Ruiz-Carus R, Matheson JRE, Roberts JDE, Whitfield PE

Editorial responsibility: John Choat,

Townsville, Queensland, Australia
(2006) The western Pacific red lionfish, Pterois volitans (Scorpaenidae), in Florida: evidence for reproduction and parasitism in the first exotic marine fish established in state waters. Biol Conserv 128:384-390

Sadovy Y, Eklund AM (1999) Synopsis of biological data on the Nassau grouper, Epinephelus striatus (Bloch, 1792), and the jewfish, E. itajara (Lichtenstein, 1822). NOAA Tech Rep NMFS 146:1-68

Semmens BX, Buhle ER, Salomon AK, Pattengill-Semmens CV (2004) A hotspot of non-native marine fishes: evidence for the aquarium trade as an invasion pathway. Mar Ecol Prog Ser 266:239-244

Snyder D, Burgess G (2007) The Indo-Pacific red lionfish, Pterois volitans (Pisces: Scorpaenidae), new to Bahamian ichthyofauna. Coral Reefs 26:175

Whitfield PE, Gardner T, Vives SP, Gilligan MR, Courtenay WR, Ray GC, Hare JA (2002) Biological invasion of the Indo-Pacific lionfish Pterois volitans along the Atlantic coast of North America. Mar Ecol Prog Ser 235:289-297

> Whitfield PE, Hare JA, David AW, Harter SL, Muñoz RC, Addison CM (2007) Abundance estimates of the IndoPacific lionfish Pterois volitans/miles complex in the Western North Atlantic. Biol Invasions 9:53-64

Wilcove DS, Rothstein D, Dubow J, Phillips A, Losos E (1998) Quantifying threats to imperiled species in the United States. BioScience 48:607-615

Williams WI, Polunin PN (2001) Large-scale associations between macroalgal cover and grazer biomass on middepth reefs in the Caribbean. Coral Reefs 19:358-366

Submitted: April 21, 2008; Accepted: June 22, 2008

Proofs received from author(s): August 27, 2008 